Cleptes pallipes Lepeletier synonym of Cleptes semiauratus (Linnaeus) and description of Cleptes striatipleuris sp. nov. (Hymenoptera: Chrysididae, Cleptinae)

\title{
Rosa, Paolo
}

2015-11-06

Rosa , P , Forshage , M , Paukkunen , J \& Soon , V 2015 , ' Cleptes pallipes Lepeletier synonym of Cleptes semiauratus (Linnaeus) and description of Cleptes striatipleuris sp. nov.

(Hymenoptera: Chrysididae, Cleptinae) ' , Zootaxa , vol. 4039 , no. 4 , pp. 543-552 . https://doi.org/10.11646/zootaxa

http://hdl.handle.net/10138/168389

https://doi.org/10.11646/zootaxa.4039.4.4

cc_by

publishedVersion

Downloaded from Helda, University of Helsinki institutional repository.

This is an electronic reprint of the original article.

This reprint may differ from the original in pagination and typographic detail.

Please cite the original version. 
http://dx.doi.org/10.11646/zootaxa.4039.4.4

http://zoobank.org/urn:lsid:zoobank.org:pub:DF06F207-0801-4043-947D-4B0F4AA58235

\title{
Cleptes pallipes Lepeletier synonym of Cleptes semiauratus (Linnaeus) and description of Cleptes striatipleuris sp. nov. (Hymenoptera: Chrysididae, Cleptinae)
}

\author{
PAOLO ROSA ${ }^{1,6}$, MATTIAS FORSHAGE ${ }^{2,3}, J_{U H O}$ PAUKKUNEN ${ }^{4} \&$ VILLU SOON 5 \\ ${ }^{1}$ Via Belvedere 8/d, I-20881 Bernareggio (MB), Italy. E-mail: rosa@chrysis.net \\ 2Station Linné, Ölands Skogsby 161, SE-386 93 Färjestaden, Sweden. E-mail: generelle.morphologie@gmail.com \\ ${ }^{3}$ Swedish Museum of Natural History, Box 50007, SE-104 05 Stockholm, Sweden. \\ ${ }^{4}$ Finnish Museum of Natural History, Zoology Unit, PO Box 17, FI-00014 University of Helsinki, Finland. \\ E-mail: juho.paukkunen@helsinki.fi \\ ${ }^{5}$ Natural History Museum and Institute of Ecology and Earth Sciences, University of Tartu, Vanemuise 46, 51014 Tartu, Estonia. \\ E-mail:villu.soon@ut.ee \\ ${ }^{6}$ Corresponding author. E-mail: rosa@chrysis.net
}

\begin{abstract}
The interpretation of Linnaeus' name Sphex semiaurata Linnaeus, 1761 has been controversial. After type examinations, we conclude that it is identical with the common Cleptes pallipes Lepeletier, 1806 and thus re-establish the old synonymy: Cleptes semiauratus (Linnaeus, 1761) (=Cleptes pallipes Lepeletier, 1806, syn. reinst.). We have been unable to find an available name for the species with which it has been confused. In order to be able to designate a suitable type specimen, we prefer to describe it as a new species rather than suggest a replacement name: Cleptes striatipleuris Rosa, Forshage, Paukkunen \& Soon sp. nov. (=Cleptes semiauratus sensu Lepeletier, 1806, nec Linnaeus, 1761; =C. splendens sensu Linsenmaier 1959, nec Fabricius, 1798).
\end{abstract}

Key words: Cleptes, new species, synonym

\section{Introduction}

Cleptes Latreille, 1802 is the largest genus in the subfamily Cleptinae, the earliest diverging extant lineage of Chrysididae (Kimsey \& Bohart 1991), which previously has been commonly treated as a separate family (Cleptidae). The genus includes 100 recognized species, mostly distributed in the Holarctic region (Kimsey \& Bohart 1991, Móczár 2009, Wei et al. 2013, Arens 2014). Móczár (1962) and Kimsey (1981) divided the genus into eight subgenera, which were later found to be indistinctly defined, particularly when the Asian species were considered. Therefore Kimsey \& Bohart (1991) synonymised the subgenera and replaced them with eight species groups. The genus was recently revised by Móczár (1996, 1997a, b, 1998a, b, c, 2000a, b, 2001), who checked almost all the available types and designated some neo- and lectotypes. Thanks to this fundamental work, it has been possible to clarify the chaotic taxonomy of the different species groups.

Sphex semiaurata Linnaeus, 1761, described from Scania (Skåne, Sweden), is the oldest name in the genus Cleptes, and the sole species at generic description (Latreille 1802), thus type species by monotypy. Several species were described over the following years in the genus, including Cleptes pallipes Lepeletier, 1806 from the surroundings of Paris.

Dahlbom (1854) synonymised $C$. pallipes with $C$. semiauratus, and this interpretation was followed by Mocsáry (1889) and Dalla Torre (1892). Then du Buysson (1891) reinstated C. pallipes as a valid species following Lepeletier's (1806) work, while Berland \& Bernard (1938) considered C. pallipes as a variation of C. semiauratus, and Móczár $(1949,2001)$ supported the validity of $C$. pallipes on the basis of the male genitalia. However, Linsenmaier (1959) treated C. pallipes as a synonym of $C$. semiauratus and used the name C. splendens (Fabricius, 
1798) (incorrect subsequent spelling for C. splendidus (Fabricius, 1794)) for C. semiauratus sensu Lepeletier, du Buysson and Móczár. Kimsey \& Bohart (1991) followed Móczár's (1949) interpretation and listed C. semiauratus and $C$. pallipes as valid species, but their illustrations of $C$. semiauratus were actually of $C$. pallipes (Móczár 2001). These mistakes have caused many incorrect determinations in collections and the subsequent literature.

Apparently, the confusion between Cleptes semiauratus and C. pallipes was originally caused by Lepeletier (1806), who listed three Cleptes species in his work (C. semiaurata, C. nitidula and C. pallipes). It is likely that $C$. semiauratus sensu Lepeletier is actually $C$. striatipleuris sp. nov., whereas $C$. pallipes is the junior synonym of $C$. semiauratus (Linnaeus). According to Lepeletier, C. semiauratus has russet brown legs ("Cette espèce a les pieds d'un roux brun") whereas C. pallipes has pale ferruginous legs ("Pieds entièrement d'un ferrugineux pâle"). It is clear that Lepeletier had not read Linnaeus' description of Sphex semiaurata (with "tibiae ferruginae"), and he had also not seen the description and drawing of Ichneumon auratus Panzer (1798). It would have been easy to think that Lepeletier's confusion was caused by the different colouration of the sexes, because C. semiauratus (Linnaeus) was described from a male and $C$. pallipes Lepeletier from a female, but this seems not to be the case. In his work, Lepeletier (1806) wrote that the sexes of $C$. semiauratus have different coloration ("Ce mále differe de la femelle en ce qu'il a la tète et le corcelet d'un verd bleuátre ainsi que les cuisses. Ces parties sont d'un doré brillant dans la femelle"). He also seemed to think that Vespa rufescens Geoffroy was conspecific with C. semiauratus. It remains a mystery why Lepeletier confused the names of the two species. Nevertheless, he was the first author who noticed that there are two separate species in the $C$. semiauratus species group.

Móczár (1996, 1997a, b, 1998a, b, c, 2000a, b, 2001) examined dozens of types in his meticulous study, but he could not examine the lectotype of Sphex semiaurata Linnaeus (Móczár 2001). He considered C. semiauratus and C. pallipes as valid species in the C. semiauratus species-group, and doubts were recently published in the checklist of the Nordic and Baltic countries (Paukkunen et al. 2014). In particular, the alleged overlapping distribution of the two species in the Northern countries is questionable, because all the examined specimens from Fennoscandia, Denmark and the Baltic countries belong to C. pallipes only (Paukkunen et al. 2014), also those identified by Móczár as C. semiauratus sensu du Buysson and Móczár. In the light of this, it has seemed probable that $C$. semiauratus in fact is the oldest available name for this taxon. The pictures of the type specimens of Sphex semiaurata on the web-site of the Linnean Society (http://innean-online.org/) have bolstered the doubts that the Sphex semiaurata could very well be conspecific with $C$. pallipes.

\section{Material and methods}

Photographs of the type specimens were taken with a reversed Helios-44M-4 lens mounted on Canon Power-Shot A710 IS digital camera, and stacked with the software Combine ZP (Soon 2010). Pictures of other specimens were taken with Keyence VHX 2000 digital photomicroscope; photographs of genitalia with a Scanning Electron Microscope (SEM) Jeol 5610 LV.

Morphological terminology follows that of Kimsey \& Bohart (1991). Abbreviations used in the text are as follows: F1, F2, F3, etc. $=$ flagellomere 1, flagellomere 2 flagellomere 3, etc., $\mathbf{P}=$ pedicel; $\mathbf{P D}=$ puncture diameter; $\mathbf{T 1}, \mathbf{T} 2, \mathbf{T 3}$, etc. $=$ metasomal tergite 1,2, 3, etc.

Types and other specimens have been examined from the following institutions:

BMNH Natural History Museum, London, UK.

LSUK Linnean Society, London, UK.

HNHM Hungarian Natural History Museum, Budapest, Hungary.

MNHN National History Museum, Paris, France.

MZH Finnish Museum of Natural History, University of Helsinki, Finland.

NMLS NaturMuseum Luzern, Switzerland.

TUZ Natural History Museum, University of Tartu, Estonia.

ZMHB Museum für Naturkunde der Humboldt-Universität, Berlin, Germany.

ZMUC Zoological Museum, University of Copenhagen, Denmark. 
Observations. Linnaeus (1761: 413) described Sphex semiaurata based on an unknown number of male specimens collected in Scania [Skåne], the southernmost province of Sweden, by his famous disciple Daniel Solander. No date is given, but Solander spent several months in Skåne in 1759 on his way to England, staying in Lund and visiting Malmö, Landskrona, Barsebäck and Ramlösa, studying the flora mainly in the latter locality (Solander in litt 1759), which might possibly be the type locality for this wasp. Day (1979: 72) designated one male as the lectotype of S. semiaurata in the LSUK; a second specimen became a paralectotype.

Kimsey (in Kimsey \& Bohart 1991: 63) designated another lectotype of S. semiaurata at MNHN based on a male specimen collected at Paris, which is neither a syntype nor the lectotype. It cannot be a syntype because the locality Paris is not mentioned in the original description and Linnaeus' types are not deposited in MNHN; moreover, the designation was done irrespectively of the previous lectotype designation by Day. According to the Code (ICZN 1999: Article 74.2) the specimen housed in MNHN is not a lectotype.

During a research visit to the LSUK, one of us (M.F.) could finally examine the lectotype of Sphex semiaurata designated by Day, bearing the labels: semiaurata $<$ handwritten by Linnaeus $>/ /$ Lectotype Sphex $\widehat{\partial}$ semiaurata L. det. M.C. Day, 1977 // Lectotype <rounded blue label $>$.

The Linnaean lectotype is rather pale in colour. It is dirty, and the dark coloration looks generally dull on superficial inspection. Tibiae are all of the same light yellowish brown tint, somewhat darker on dorsal side than ventral, somewhat darker on proximal parts than apical, with pale setae and no trace of metallic lustre. Mesopleuron with row of deep foveae along the antero-lateral edge; anterior part of dorsal half with rather shallow foveae and longitudinally extended to form some kind of striae, while the posterior part is bulging with only sparsely scattered punctures, two of which are deep enough to be called small foveae. Ventral half of mesopleuron entirely covered with foveae of different sizes, with no apparent tendency to form longitudinal striae (as in $C$. semiauratus sensu Móczár 2001: Fig. 7). Metapleuron clearly foveolate in its dorsalmost parts (as in C. pallipes sensu Móczár 2001: Fig. 8), but rather smooth, shallowly foveolate and not striate in ventral part. Dark pattern of metasoma forms a forward-pointing triangle on T3, while the entirely dark T4 has faint but undeniable violet/ purple sheen, and $\mathrm{T} 5$ is in fact dark metallic blue.

The last valid diagnostic character to separate the two species is the shape of genital capsule. Móczár (2001: Figs 13, 14, 17) and Rosa (2006: Figs 13, 14) illustrated the genital capsule of both species, which are evidently different. The examination of genitalia in the type of $S$. semiaurata is not allowed because the type could be easily broken.

Despite the non-examined genital capsule, all the studied characteristics, such as: yellowish tibiae, foveolate lower mesopleuron, violet-tinted T4 and metallic T5, allow us to conclude that the lectotype of Sphex semiaurata Linnaeus is conspecific with the common North European species currently known as C. pallipes Lepeletier.

We (P.R.) examined the female holotype of C. pallipes Lepeletier, 1806 in MNHN. Morgan (1984: 10) designated this specimen as the lectotype. However, the type is a holotype by monotypy because Lepeletier (1806) based the description on a single female "L'insecte décrit étoit une femelle. Je ne connois pas le mâle. Des environs de Paris".

After these type examinations, we can state that Sphex semiaurata Linnaeus, $1761=$ Cleptes pallipes Lepeletier, 1806 syn. reinst.

Furthermore, we (P.R.) examined the other available types related to $S$. semiauratus and $C$. pallipes, with the exception of the types of Ichneumon auratus Panzer, 1798 and Vespa rufescens Geoffroy, 1785, whose repositories are unknown (Kimsey \& Bohart 1991). This research was necessary looking for the first available name for the species known as C. semiauratus sensu Lepeletier, du Buysson and Móczár or C. splendens sensu Linsenmaier. Based on this examination, we can state that:

(1) Vespa rufescens Geoffroy in Fourcroy, 1785, appears to have no extant type material (Kimsey \& Bohart 1991) and we did not find it during our research in MNHN. V. rufescens has been historically considered as a synonym of C. semiauratus (Lepeletier 1806, Mocsáry 1889: 47, Dalla Torre 1892: 5, Kimsey \& Bohart 1991: 64, Mingo 1994: 196). However, its description is too short, without any diagnostic characteristics, and fitting several different species in the genus Cleptes: "La Guêpe dorée cuivreuse à ventre fauve \& noir. Long. 2 lig. Larg. 1/2 lig.". We follow the interpretation and synonymy proposed by the elder authors, and we also observe that the synonymy of $V$. rufescens with $C$. semiauratus is probable also considering the type locality Paris. In fact, in all the main European chrysidid collections (HNHM, MNHN, NMLS, ZMUC) C. semiauratus sensu Lepeletier, du Buysson and Móczár is relatively common only in Southern France and the Alps, whereas no specimens with confirmed 
identifications are available from the surroundings of Paris or northern France. According to Móczár (2001), the distribution of the species seems to be limited to southern France (Le Vernet and Saint-Genis-les-Ollières).

(2) Cleptes splendidus (Fabricius, 1794), listed as a synonym of C. semiauratus by Kimsey \& Bohart (1991) is a valid species in the $C$. nitidulus species-group, as demonstrated by Móczár (1998b).

(3) Cleptes splendens (Fabricius, 1798) is an invalid subsequent spelling of C. splendidus (Fabricius, 1794).

(4) Ichneumon auratus Panzer, 1798, appears to have no extant type material (Kimsey \& Bohart 1991) and we did not find it during our research in ZMHB. However, the colour illustration (Panzer 1798: tab. 1) is accurate and clearly depicts a female of $C$. semiauratus $(=C$. pallipes) based on the general habitus, yellowish colour of scape, pedicel and first four flagellomeres, pale yellow non-metallic colour of all legs, metallic blue T4, and extended darkened bands on wings. The species has been traditionally considered as a synonym of C. semiauratus (Dahlbom 1854: 16, Mocsáry 1889: 48, Dalla Torre 1892: 5, Kimsey \& Bohart 1991: 64, Mingo 1994: 196), but it was not included by Móczár in his revision of the Cleptes species. We agree with the previous interpretation of elder authors and consider I. auratus Panzer as a junior synonym of $C$. semiauratus.

(5) Cleptes aurata Dahlbom, 1845, nom. praeocc., nec Panzer, 1798 is a valid species belonging to the $C$. dahlbomi species group. The original type is lost (Rosa \& Vårdal 2015) but Móczár (1998c) designated a neotype.

(6) Cleptes diana Mocsáry, 1889, whose type is a male housed in HNHM and dissected by Móczár, is truly a junior synonym of $C$. pallipes, as already recognized by Kimsey \& Bohart (1991) and Móczár (1949, 2001), and therefore it is a synonym of $C$. semiauratus (Linnaeus, 1761) too.

(7) Cleptes dahlbomi Semenov-Tian-Shanskij, 1920 is the replacement name for C. aurata Dahlbom, 1845, nom. praeocc., nec Panzer, 1798.

As a consequence, Cleptes semiauratus sensu Lepeletier 1806, du Buysson 1891, and Móczár 2001, nec Linnaeus, 1761 (=C. splendens sensu Linsenmaier 1959, nec Fabricius, 1798) must be considered as a misidentification of an undescribed species in spite of the many descriptions in the literature (references in species description below). Technically, a replacement name (nomen novum) for the erroneous and homonymic use of $C$. semiauratus would have been in order. However, since in that case any specimen seen by Lepeletier before his publication would be a syntype, we have chosen to describe it as a new species. This allows us to choose a fresh and readily available specimen as the name-bearing type, which has been considered much preferable to an uncertain number of old and uncertain syntypes.

\section{Cleptes semiauratus (Linnaeus, 1761)}

= Vespa rufescens Geoffroy, 1785.

= Ichneumon auratus Panzer, 1798 .

= Cleptes pallipes Lepeletier, 1806 .

= Cleptes diana Mocsáry 1889 .

Sphex semiaurata Linnaeus 1761: 413. Lectotype đึ (designation by Day 1979: 2); Sweden: Scania (LSUK). Chrysis semiaurata: Fabricius 1775: 359.

Vespa rufescens Geoffroy, 1785: 441. Holotype $\bigcirc$; France: Paris (depository unknown).

Ichneumon auratus Panzer, 1798: heft 52 (26). Holotype 9 ; Germany (depository unknown).

Cleptes semi-auratus: Latreille 1802: 316.

Cleptes semiaurata: Fabricius 1804: 154; Dahlbom 1831: 23; 1845: 2; 1854: 15.

Cleptes pallipes Lepeletier, 1806: 119. Holotype 9 ; France: sorroundings of Paris (MNHN); Latreille 1809: 449; du Buysson in André 1891: 83, 90, Plate 4 (Fig. 4); 1898: 545, 563, 566; 1900: 125; 1901: 97; Semenov-Tian-Shanskij 1920: 317 ; Móczár: 1949: 42; 1951: 264, 274, 275 (Figs 20-21); 1962: 117; 1967: 6; 2001: 905, 908, 911 (Fig. 8), 912 (Figs 1314), 917; Zimmermann 1954: 1; Kusdas 1956: 326; Mingo 1994: 29, 31, 32 (Figs 8c, 8d); Strumia 1995: 2; Rosa 2005 : 8, 2006: 51, 55, 57, 86, 93, Plate I (Figs 9, 14); Schljachtenok 2006: 286; Strumia \& Yıldırım 2008: 56, 81; Turrisi 2009: 299, 300 (Fig. 8, ơ; Tyrner et al. 2010: 46; Szczepko \& Wiśniowski 2009: 170; Orlovskyte et al. 2010: 145; Burger \& Sobczyk 2011: 53, 54, 55; Szczepko et al. 2012: 7; Macek et al. 2012: 44, 45 (Fig. 2); Pavesi \& Rosa 2013: 48; Paukkunen et al. 2014: 9.

Cleptes semiauratus: Mocsáry 1882: 19; 1889: 47 (partim); Dalla Torre 1892: 5; Linsenmaier 1959: 10; Gauss 1964: 225,227 (Fig. 1, Ĵ, ๆ); Morgan 1984: 10 (lectotype design. + of C. pallipes Lepeletier, MNHN), 14, 35 (Fig. 91); Gould \& Bolton 1988: cover image (q), 230 (Fig. 136, q); Kimsey \& Bohart 1991: 54 (Fig. 11, )), 55 (Figs 12c, 12f), 63; Kunz 1994: 47, 72, 73 (Fig. 159, m, +); Linsenmaier 1997: 31, 42, 45 (colour drawings); Mandery \& Niehuis 2000: 52; Niehuis 2001: 121; Yıldırım \& Strumia 2001: 163; Peeters 2004: 186 (Fig. 7); Rosa 2006: Plate I (Fig. 12); Tyrner 2007: 46. 
Cleptes Diana Mocsáry 1889: 46. Holotypus đ̊̄; Greece (HNHM); Dalla Torre 1892: 2.

Cleptes semiauratus var. pallipes: Housiaux 1922: 24, 25.

Cleptes semiaurata var. pallipes: Berland \& Bernard: 1938: 20, 23.

\section{Cleptes striatipleuris Rosa, Forshage, Paukkunen \& Soon, sp. nov.}

(Figs 1A-1B; 2A-2F)

Cleptes semiaurata: Lepeletier 1806: 119; Móczár 1951: 273, 275 (Figs 22-23).

Cleptes semiauratus: du Buysson 1891: 91, Plate 4 (Fig. 3), Plate 6 (Fig. 6); 1898: 545, 563; Mocsáry $1889: 47$ (part.); Semenov-Tian-Shanskij 1920: 316; Housiaux 1922: 24, 25; Berland \& Bernard 1938: 20, 22, Móczár 1949: 42; 1962: 117; 1967: 3 (Fig. 2C), 5; 2001: 905, 907, 908, 911 (Fig. 7), 912 (Fig. 17), 924; Zimmermann 1954: 1; Kusdas 1968: 81, 84; Kimsey 1981: 810 (Fig. 19), 813 (Fig. 29), 815; Bohart \& Kimsey 1982: 12, 14, 220 (Fig. 7); Mingo 1994: 28, 31 , 32 (Figs 8a, 8b); Linsenmaier 1997: 10 (fig. 5, genital capsule), 31, 45 (colour drawing, ô); Yıldırım \& Strumia 2001: 163; Rosa 2005: 7, 2006: 38, 51, 55, 57, 84, 86, 95 (Plate I, Fig. 13); Strumia \& Yildırım 2008: 81; Oliveira et al. 2009: 39; Burger \& Sobczyk 2011: 53, 54, 55; Rosa \& Zettel 2011: 197; Macek et al. 2012: 44, 45 (Fig. 3).

Cleptes pallipes: Kimsey \& Bohart 1991: 62; Rosa 2006: Plate I (Fig. 11); Turrisi 2009: 299, 300 (, Figs 4-7).

Cleptes splendens: Linsenmaier 1959: 10; Kunz 1994: 47, 73 (Fig. 142, đ̋, o); Strumia 1995: 1; Linsenmaier 1997: 31, 43, Straka et al. 2004: 144; Tyrner 2007: 46.

Material examined. Holotype $\widehat{\partial}$ (Fig. 1A): Hungary, Veröce, $35 \mathrm{~km} \mathrm{~N}$ Budapest, $\left(47^{\circ} 49.58^{\prime} \mathrm{N} 19^{\circ} 01.30^{\prime} \mathrm{E}\right), 21-$ 30.V.2005, Malaise trap, leg. Z. Nyiro (deposited in TUZ, ID: TUZ616003, secondary ID: BBSL657480). Paratype 1 ( Fig. 1B): Hungary, Verőce, 35 km N Budapest, (47²9.58'N 1901.30'E), 28.VI-20.VII.2005, Malaise trap, leg. Z. Nyiro (deposited in TUZ, ID: TUZ616004, secondary ID: BBSL662380).

Diagnosis. $C$. striatipleuris sp. nov. is very similar to $C$. semiauratus in shape and structure, except: middle and hind tibiae dark brown; metasomal terga without metallic lustre, occasionally on T5; mesopleuron with oblique striae (Figs 2D, 2E); male genitalia (as in Fig. 2F). To date this species is thoroughly described by Móczár (2001: 924). A SEM picture of the mesopleuron is available in Móczár (2001: 911, Fig. 7), and another picture of the genital capsule is available in Rosa (2006: Plate I, Fig. 13), line drawings of the genital capsule are available in Móczár (1949: 275, Figs 22-23; 2001: 912, Fig. 17), and line drawings of the pronotum and mesosoma are available in Móczár (1967: 23, Fig. 2C). Despite the existing earlier descriptions the species must be described as new in order to establish a new valid name for this taxon.

Description. MALE (holotype). Body length $6.5 \mathrm{~mm}$, forewing length $4 \mathrm{~mm}$.

Head. Height $1.1 \mathrm{~mm}$, width $1.5 \mathrm{~mm}$, shortest interocular distance $0.9 \mathrm{~mm}$, malar space 1.4 times broader than high. Head colour metallic blue with some greenish tint. Head moderately punctate with interstices between punctures 1-2 PD wide and polished. Mandible blackish brown with proximal half metallic green. Scape green, the rest of antennae dark brown, nearly black. Relative lengths of P:F1:F2:F3 = 1:1.9:1.3:1.1. Pubescence on head dark brown.

Mesosoma. Length $2.6 \mathrm{~mm}$, width $1.5 \mathrm{~mm}$. Colour metallic blue with some greenish tint, propodeum posteriorly partly black. Pronotum similarly punctate as head with polished interstices of $2 \mathrm{PD}$ wide. Posterior edge of pronotum with row of 4 large and few smaller foveae. Mesonotum sparsely punctate with polished interstices $2-$ 3 PD wide. Mesopleuron, especially on latero-ventral half, with numerous strigose and elongate foveae, largely fused forming oblique striae. Propodeum dorsally with rugose irregular carinae. Lateral propodeal teeth acute. Pubescence on mesosoma dark, brownish. Fore-femur greenish, rest of foreleg light brown, mid- and hind-legs dark brown with more or less green sheen on femora. Wing venation typical for Cleptes.

Metasoma. Length $2.7 \mathrm{~mm}$, maximum width $1.7 \mathrm{~mm}$, with five external segments. T1 and T2 testaceous, T3 testaceous proximally, slightly brownish centrally and dark brown distally, T4 and T5 black. Metasoma without metallic lustre except faint bluish sheen on T5. T1 polished proximally, without punctures, rest of the metasoma with small punctures with interstices 1-3 PD wide being sparser proximally and denser distally. Pubescence yellowish. Genital capsule (as in Fig. 1F).

FEMALE (paratype). Similar to male holotype except for the following characteristics: relative lengths of $\mathrm{P}: \mathrm{F} 1: \mathrm{F} 2: \mathrm{F} 3=1: 1.1: 0.5: 0.5$; pubescence throughout yellowish; body colour, with head, pronotum, mesonotum, metanotum medially and frontal plus ventral part of mesopleuron metallic coppery-golden; rest of mesosoma metallic blue. Scape metallic coppery, pedicel brown, F1 and F2 yellow, F3 light brown, rest of antenna brown. Metasoma with four external segments. Forewing medially banded. 


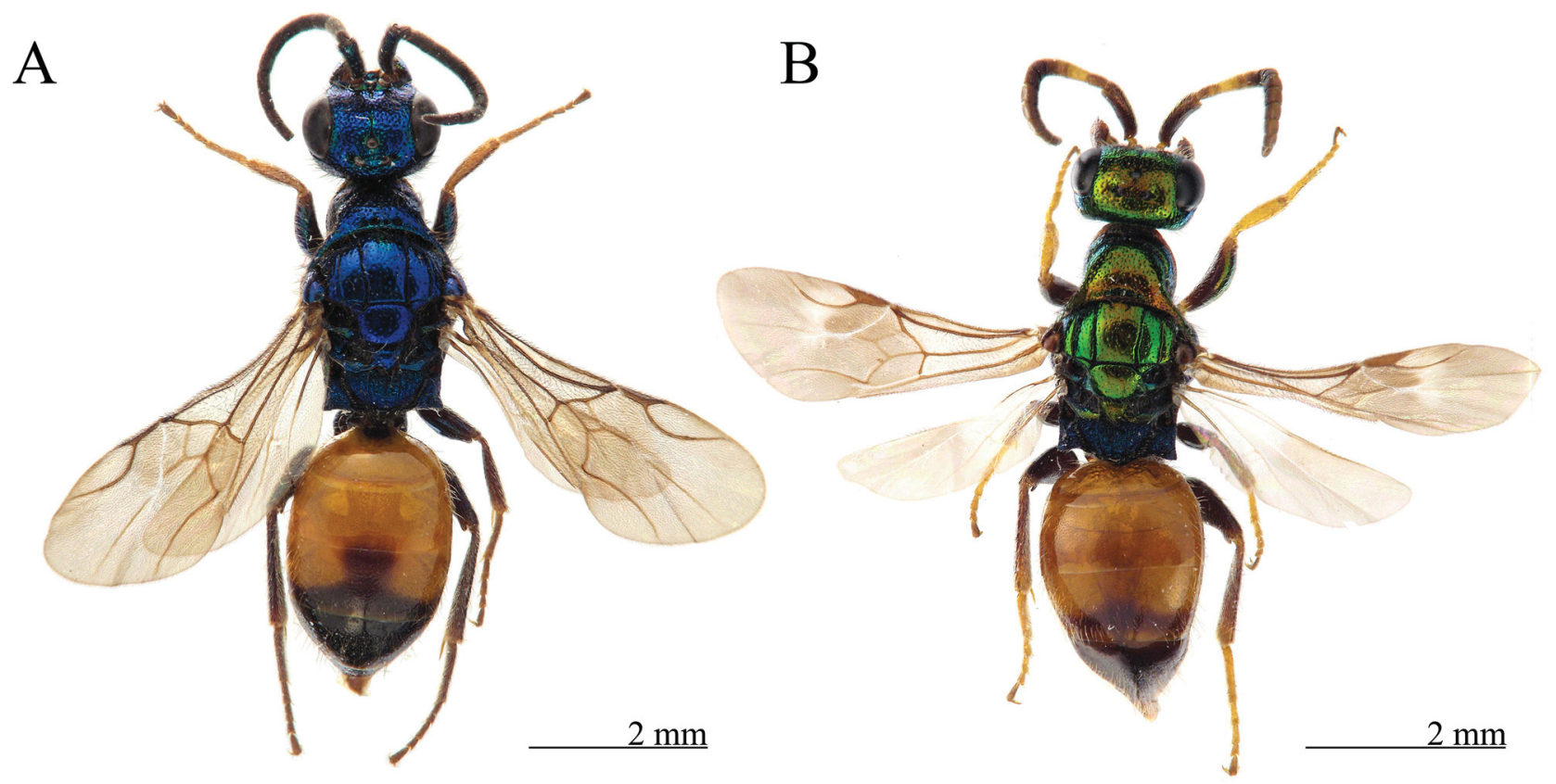

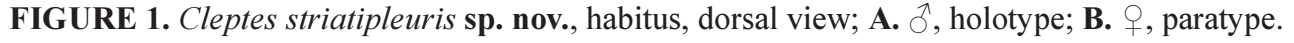

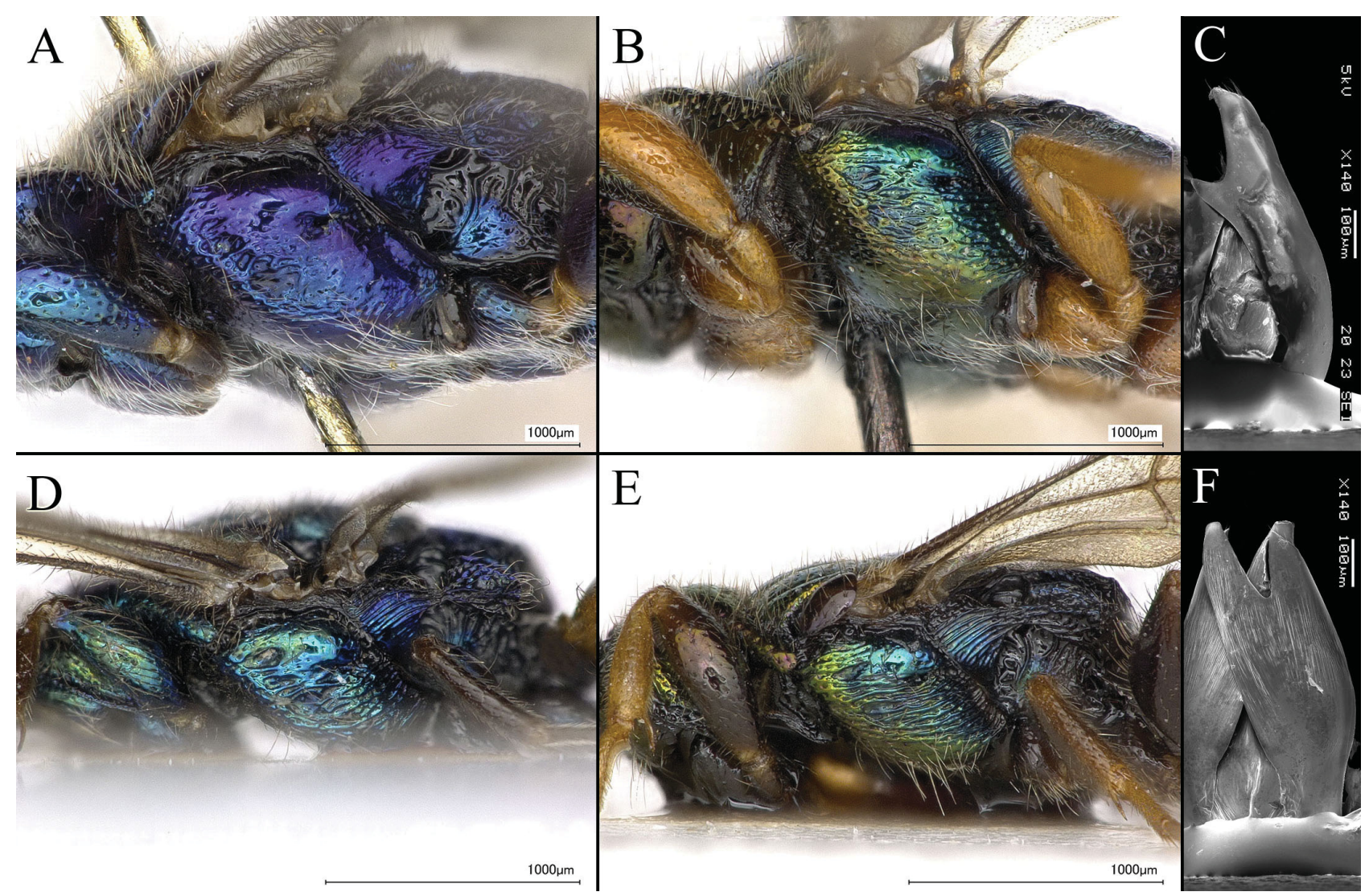

FIGURE 2. A-C. Cleptes semiauratus (Linnaeus); A. Mesopleuron, Ô, Italy, Piedmont, San Mauro (TO), $210 \mathrm{~m}$; B. Mesopleuron,, , the same locality; C. Genital capsule, Õ , Aosta Valley, Pondel, 880 m. D-F. C. striatipleuris sp. nov.; D.

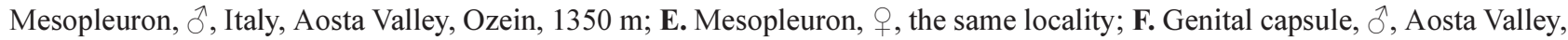
Ozein, 1350 m.

Remarks. The left mid-leg of the holotype is removed and deposited in TUZ for the extraction of DNA; the last flagellomere of left antenna of the holotype is missing. 
Distribution. At present, the European distribution of $C$. striatipleuris sp. n. seems to be restricted to central and southern Europe. In fact, the English locality given by Móczár (2001), Torla, is actually in Spain, whereas the specimens listed Móczár (2001) for northern Europe (Denmark) in ZMUC were later identified as C. semiauratus (Paukkunen et al. 2014, sub C. pallipes). Based on the pictures and descriptions given by Kimsey (1981) and Bohart \& Kimsey (1982), the species is also distributed in the Nearctic Region.

Etymology. The specific name refers to the striate mesopleuron, one of the diagnostic characteristic valid for species identification when compared with the similar Cleptes semiauratus. It is an adjective in the masculine case based on the Latin stria (line) and the Greek pleuron (side).

\section{Acknowledgements}

We thank Mike Fitton (Linnean curator) for making the type of $C$. semiauratus available, and David Notton at the BMNH for hosting MF. We are grateful to the following curators for their cooperation and assistance in the study of the type material: Zoltán Vas (HNHM), Marco Bernasconi (NMLS), Frank Koch (ZMHB), Claire Villemant and Agnièle Touret-Alby (MNHN), Lars Vilhelmsen (ZMUC). We are also grateful to Michele Zilioli (Museo di Storia Naturale, Milano) for the SEM pictures of the genital capsules, and Hannes Baur (Naturhistorisches Museum, Bern) for taking photographs of some specimens. We are also very grateful to Arkadiy Lelej (Russia) and two anonymous reviewers for their kind suggestions to improve the manuscript.

\section{References}

Arens, W. (2014) Die Goldwespen der Peloponnes (Hymenoptera: Chrysididae) 1. Teil: Die Gattungen Cleptes, Omalus, Holopyga, Hedychrum, Hedychridium und Euchroeus; mit Beschreibung einer neuen Cleptes-Art. Linzer Biologische Beiträge, 46 (1), 553-621.

Berland, L. \& Bernard, F. (1938) Hyménoptères vespiformes. III. (Cleptidae, Chrysidae [!], Trigonalidae). Faune de France. Vol. 34. Paul Lechevalier, Paris, vii +145 pp.

Bohart, R.M. \& Kimsey, L.S. (1982) A synopsis of the Chrysididae in America North of Mexico. Memoirs of the American Entomological Institute, 33, 1-266.

Burger, F. \& Sobczyk, T. (2011) Zu einem syntopen Vorkommen von Cleptes pallipes Lepeletier, 1806, C. semiauratus (Linnaeus, 1761) und C. nitidulus (Fabricius, 1793) in Sachsen mit neuen Erkenntnissen zur Determination der Gattung Cleptes in Deutschland (Hymenoptera, Chrysididae). Entomologische Nachrichten und Berichte, 55 (1), 53-56.

Buysson, R. du (1891-1896) Les Chrysides. In: André, E. (Ed.), Species des Hyménoptères d'Europe \& d'Algerie. Tome Sixième. Vve Dubosclard, Paris, pp. I-XII + 13-758 + 64 unnumbered pages + pls. 1-32 (1891) pp. 1-88, (1892) pp. 89208, (1893) pp. 209-272, (1894) pp. 273-400, (1895) pp. 401-624, (1896) pp. 625-756 + 1-22, (1891-1896) unnumbered pages 1-64+ pls. 1-32. [dating after Derksen \& Scheiding 1963] http://dx.doi.org/10.5962/bhl.title.10281

Buysson, R. du (1898) Étude des Chrysidides du Muséum de Paris. Annales de la Societe Entomologique de France, 66 (4), $518-580$.

Buysson, R. du (1900) Contribution aux Chrysidides du Globe (4 série). Revue d'Entomologie, 19 (8-9), 125-160, pls. 1, 2.

Buysson, R. du (1901) Sur quelques Chrysidides du Musée de Vienne. Annalen des $k$. $k$. Naturhistorischen Hofmuseums in Wien, $16(1), 97-104$.

Dahlbom, A.G. (1831) Exercitationes Hymenopterologicae. Monographia Chrysididum Sveciae (Familia Hymenopterorum Octava Latreille). Pars II \& III (partim). Londini Gothorum, 14 pp. \& 16 pp. [Pars II pp. 19-32; Pars III, 33-48, Chrysididae 33-36]

Dahlbom, A.G. (1845) Dispositio Methodica Specierum Hymenopterorum, secundum Familias Insectorum Naturales. Particula secunda. Chrysis in sensu Linnceano. Berlingianis, Lund, 20 pp. http://dx.doi.org/10.5962/bhl.title.66977

Dahlbom, A.G. (1854) Hymenoptera Europaea praecipue borealia, formis typicis nonnullis specierum generumve Exoticorum aut Extraneorum propter nexum systematicum associatis, per familias, genera, species et varietates disposita atque descripta. 2. Chrysis in sensu Linnceano. Friedrich Nicolai, Berlin, xxiv +412 pp. +12 pls. http://dx.doi.org/10.5962/bhl.title.15890

Dalla Torre, K.W. (1892) Catalogus hymenopterorum hucusque descriptorum systematicus et synonymicus. Volumen VI. Chrysididae (Tubulifera). Wilhelm Engelmann, Lipsiae, ix +118 pp.

http://dx.doi.org/10.5962/bhl.title.10348

Day, M.C. (1979) The species of Hymenoptera described by Linnaeus in the genera Sphex, Chrysis, Vespa, Apis and Mutilla. 
Biological Journal of the Linnean Society, 12, 45-84.

http://dx.doi.org/10.1111/j.1095-8312.1979.tb00049.x

Fabricius, J.C. (1775) Systema entomologiae, sistens Insectorum classes, ordines, genera, species, adiectis synonimis, locis, desriptionibus, observationibus. Korti, Flensburgi et Lipsiae, 832 pp.

http://dx.doi.org/10.5962/bhl.title.36510

Fabricius, J.C. (1794) Entomologia Systematica emendata et aucta secondum classes, ordines, genera, species adjectis synonimis, locis, observationibus, descriptionibus. Tomo IV. C.G. Proft, Hafniae [= Copenhagen], vii + 472 pp. http://dx.doi.org/10.5962/bhl.title.36532

Fabricius, J.C. (1798) Supplementum entomologiae systematicae. Proft et Storch, Hafniae [= Copenhagen], [2] + 572 pp. http://dx.doi.org/10.5962/bhl.title.65803

Fabricius, J.C. (1804) Systema Piezatorum: secundum ordines, genera, species, adiectis synonymis, locis, observationibus, descriptionibus. C. Reichard, Brunsvigae, 484 pp.

Gauss, R. (1964) Cleptes semiauratus L. (Hym. Chrysididae) im Rahmen der Parasitenliste von Pristiphora abietina (Christ) (Hym. Tenthredinidae) in Südwestdeutschland. Zeitschrift für Angewandte, Entomologie, 54 (1-4), $225-232$. http://dx.doi.org/10.1111/j.1439-0418.1964.tb02937.x

Geoffroy, E.L. (1785) In: de Fourcroy, A.F. (Ed.), Entomologia Parisiensis; sive, Catalogus insectorum quae in agro Parisiensi reperiuntur. Vol. 2. Serpentineis, Paris, 311 pp. http://dx.doi.org/10.5962/bhl.title.36528

Gould, I. \& Bolton, B. (1988) The Hymenoptera. Oxford University Press and British Museum (Natural History), Oxford, 332 pp.

Housiaux, A. (1922) Les Chrysididae de Belgique. Bulletin de la Société entomologique de Belgique, 4, 19-38.

International Commission on Zoological Nomenclature (ICZN). (1999) International Code of Zoological Nomenclature. Fourth Edition. International Trust for zoological Nomenclature, London, xxx +306 pp.

Kimsey, L. (1981) The Cleptinae of the Western Hemisphere (Chrysididae: Hymenoptera). Proceedings of the Biological Society of Washington, 94, 801-818.

Kimsey, L.S. \& Bohart, R.M. (1991 ["1990"]) The Chrysidid Wasps of the World. Oxford University Press, New York, 652 pp.

Kunz, P.X. (1994) Die Goldwespen (Chrysididae) Baden-Württembergs. Taxonomie, Bestimmung, Verbreitung, Kartierung und Ökologie. Mit einem Bestimmungsschlüssel für die deutschen Arten. Beihefte zu den Veröffentlichungen für Naturschutz und Landschaftspflege in Baden-Württemberg, 77, 1-188.

Kusdas, K. (1956) Beitrag zur Kenntnis der Goldwespenfauna (Chrysididae und Cleptidae) Oberösterreich unter besonderer Berücksichtigung des Großraumes von Linz. Naturkundliches Jahrbuch der Stadt Linz, 1956, 307-326.

Kusdas, K. (1968) Über Lebensraum und Lebensweise palaearktischer Cleptes-Arten (Hym., Cleptidae). Nachrichtenblatt der bayerischen Entomologen, 17 (5), 77-86.

Latreille, P.A. (1802) Histoire naturelle générale et particuliére des Crustacés et des Insectes. Ouvrage faisant suite à l'Histoire Naturelle générale et particulière, composée par Leclercq de Buffon, et rédigée par C.S. Sonnini, membre de plusiers Sociétés savantes. Familles naturelles des genres. Tome troisième. F. Dufart, Paris, xii + 455 pp. [pp. 13-467] http://dx.doi.org/10.5962/bhl.title.15764

Lepeletier [de Saint Fargeau], [A.L.M.] (1806) Mémoire sur quelques espéces nouvelles d'insectes de la section des Hyménoptères, appelés les Porte-tuyaux, et sur les caractères de cette famille et des genres qui la composent. Annales du Muséum d'Histoire Naturelle, 7, 115-129. Available from: http://www.biodiversitylibrary.org/item/91678 (accessed 8 May 2015)

Linnaeus, C. (1761) Fauna Suecia sistens Animalia Sueciae Regni: Mammalia, Aves, Amphibia, Pisces, Insecta, Vermes. Distributa per Classes et Ordines, enera et Species, cum Differentiis, Specierum, Synonymis, Auctorum, Nominibus Incolarum, Locis natalium, Descriptionibus Insectorum. Editio Altera, Auctior. Laurentius Salvius, Stockholm, 578 pp. + 2 pls.

http://dx.doi.org/10.5962/bhl.title.46380

Linsenmaier, W. (1959) Revision der Familie Chrysididae (Hymenoptera) mit besonderer Berücksichtigung der europäischen Spezies. Mitteilungen der Schweizerischen Entomologischen Gesellschaft, 32 (1), 1-232.

Linsenmaier, W. (1997) Die Goldwespen der Schweiz. Veröffentlichungen aus dem Natur-Museum Luzern, 9, 1-140.

Macek, J., Straka, J., Bogusch, P., Dvoøák, L., Bezdì̀ka, P. \& Tyrner, P. (2012) Blanokřidlí České republiky: Žahadloví. I. Academia, Prague, 520 pp.

Mandery, K. \& Niehuis, O. (2000) Die Goldwespen (Hymenoptera: Chrysididae) der Sammlung T. Schneid im Naturkundemuseum Bamberg. Bericht der naturforschenden Gesellschaft Bamberg, 74, 45-59.

Mingo, E. (1994) Hymenoptera Chrysididae. Fauna Iberica. Vol. 6. Museo Nacional de Ciencias Naturales, Consejo Superior de Investigaciones Científicas, Madrid, 256 pp.

Mocsáry, A. (1882) Chrysididae Faunae Hungaricae. Academia Hungarica Scientiarum, Budapest, 94 pp.

Mocsáry, A. (1889) Monographia Chrysididarum Orbis Terrarum Universi. Academia Hungarica Scientiarum, Budapest, 643 pp.

Móczár, L. (1949) Les Cleptides du bassin des Karpathes. (Fam. Cleptidae, Hym.). Folia Entomologica Hungarica, N.S., 3, 40-45.

Móczár, L. (1951) Les Cleptides du Musée Hongrois d'Histoire Naturelle. Annales Historico-Naturales Musei Nationalis 
Hungarici, N.S. 1, 260-282.

Móczár, L. (1962) Bemerkungen über einige Cleptes-Arten (Hymenoptera: Cleptidae). Acta Zoologica Academiae Scientiarum Hungaricae, 8, 115-125.

Móczár, L. (1967) Chrysidoidea - Fémdarázs-Alkatúak. Hymenoptera III. Fauna Hungariae, Akadémiai Kiadó, Budapest, 86, $1-118$.

Móczár, L. (1996) New data on the Subfamily Cleptinae (Hymenoptera: Chrysididae). Acta Zoologica Academiae Scientiarum Hungaricae, 42 (2), 133-144.

Móczár, L. (1997a) Revision of the Cleptes nitidulus group of the world (Hymenoptera, Chrysididae, Cleptinae). Entomofauna, 18 (3), 25-44. Available from: http://www.landesmuseum.at/pdf_frei_remote/ENT_18_0025-0044.pdf (accessed 8 May 2015)

Móczár, L. (1997b) Revision of Cleptes (Leiocleptes) species of the world (Hymenoptera: Chrysididae, Cleptinae). Folia Entomologica Hungarica, 58, 89-100.

Móczár, L. (1998a) Revision of the Cleptes (Holcocleptes) species of the world (Hymenoptera, Chrysididae). Acta Zoologica Academiae Scientiarum Hungaricae, 43 (4), 323-343.

Móczár, L. (1998b) Supplement to the revision of Cleptes (Leiocleptes) of the world (Hymenoptera: Chrysididae, Cleptinae). Folia Entomologica Hungarica, 59, 209-211.

Móczár, L. (1998c) Revision of the Cleptinae of the World. Genus Cleptes subgenera and species groups. (Hymenoptera, Chrysididae). Entomofauna, 19 (31), 501-516. Available from: http://www.landesmuseum.at/pdf_frei_remote/ ENT_0019_0501-0514.pdf(accessed 8 May 2015)

Móczár, L. (2000)a) Revision of the Cleptes asianus and townesi groups of the world (Hymenoptera, Chrysididae, Cleptinae). Acta Zoologica Academiae Scientiarum Hungaricae, 46 (4), 319-331.

Móczár, L. (2000b) World revision of the Cleptes satoi group (Hymenoptera: Chrysididae, Cleptinae). Annales Historiconaturales Musei Nationalis Hungarici, 92, 297-324. Available from: http://publication.nhmus.hu/pdf/annHNHM/ Annals_HNHM_2000_Vol_92_297.pdf(accessed 8 May 2015)

Móczár, L. (2001) World revision of the Cleptes semiauratus group (Hymenoptera, Chrysididae, Cleptinae). Linzer biologische Beiträge, 33 (1), 905-931. Available from: http://www.zobodat.at/pdf/LBB_0033_2_0905-0931.pdf (accessed 8 May 2015)

Móczár, L. (2009) Cleptes hungaricus sp. n. and the related Palaearctic species (Hymenoptera: Chrysididae). Annales Historico-naturales Musei nationalis hungarici, 101, 131-136. Available from: http://publication.nhmus.hu/pdf/ annHNHM/Annals_HNHM_2009_Vol_101_131.pdf(accessed 8 May 2015)

Morgan, D. (1984) Cuckoo-wasps, Hymenoptera, Chrysididae. Handbooks for the Identification of British Insects. Royal Entomological Society of London, London, 6 (5), 1-37. Available from: http://www.royensoc.co.uk/sites/default/files/ Vol06_Part05.pdf (accessed 8 May 2015).

Niehuis, O. (2001) Chrysididae. In: Dathe, H.H., Taeger, A. \& Blank, S.M. (Eds), Verzeichnis der Hautflügel Deutschlands (Entomofauna Germanica, 4), Entomologische Nachrichten und Berichte, 7, 119-123.

Oliveira, de N.G., Gayubo, S.F., Strumia, F. \& Serrano, A.R.M. (2009 ["2008"]) The cuckoo-wasps (Hymenoptera, Chrysididae) of Douro internacional and Serras de Aire e Candeeiros Natural Parks and Paúl do Boquilobo Natural Reserve (Portugal). Frustula entomologica, N.S., 31, 35-51.

Orlovskyte, S., Budrienè, A. \& Budrys, E. (2010) Check-list of cuckoo-wasps (Hymenoptera: Chrysididae) of Lithuania. New and rare for Lithuania insect species, 22, 141-156.

Panzer, G.W.F. (1792-1844). Faunae Insectorum Germaniae initia oder Deutschlands Insecten. Nürnberg (1797) Hf. 39-48; (1798) Hf. 49-60; (1799) Hf. 61-72; (1800) Hf. 73-79; (1801) Hf. 80-85 (1805) Hf. 97-99; (1806-1809) Hf. $101-107$. [Dating after Sherborn, 1923].

Paukkunen, J., Rosa, P., Soon, V., Johansson, N. \& Ødegaard, F. (2014) Faunistic review of the cuckoo wasps of Fennoscandia, Denmark and the Baltic countries (Hymenoptera: Chrysididae). Zootaxa, 3864 (1), 1-67. http://dx.doi.org/10.11646/zootaxa.3864.1.1

Pavesi, M. \& Rosa, P. (2013) La collezione di Crisidi (Hymenoptera, Chrysididae) del Museo Civico di Storia Naturale di Verona. Bollettino del Museo Civico di Storia Naturale di Verona, 37, 47-66.

Peeters, T.M.J. (2004) Chrysididae - goudwespen. In: Reemer, M., Van Loon, A.J. \& Peeters, T.M.J. (Eds): De wespen en mieren van Nederland (Hymenoptera: Aculeata). Nederlanse Fauna 6, Nationaal Natuurhistorisch Museum Naturalis, Leiden, $507 \mathrm{pp}$.

Rosa, P. (2005) La collezione di Crisidi (Hymenoptera, Chrysididae) del Museo Civico di Storia Naturale di Milano. Natura, 94 (2), 1-128.

Rosa, P. (2006) I Crisidi della Valle d'Aosta. Monografie del Museo regionale di Scienze naturali, 6, St.-Pierre, Aosta, 368 pp + xvi + xxxii pls.

Rosa, P. \& Vårdal, H. (2015) An annotated catalogue of the types of Chrysididae (Hymenoptera) at the Swedish Museum of Natural History, Stockholm, with brief historical notes. ZooKeys, 495, 79-132. http://dx.doi.org/10.3897/zookeys.495.9356

Rosa, P. \& Zettel, H. (2011) Goldwespen (Chrysididae). In: Wiesbauer, H., Zettel, H., Fischer, M.A. \& Maier R. (Eds) Der Bisamberg und die Alten Schanzen Vielfalt am Rande der Großstadt Wien, Gugler Druck, St. Pölten., pp. 195-200.

Schljachtenok, A.S. (2006) Zur Kenntnis der Goldwespen Weissrusslands (Hymenoptera, Chrysididae). Entomofauna, 27 (23), 
285-292. Available from: http://www.zobodat.at/pdf/ENT_0027_0285-0291.pdf (accessed 8 May 2015)

Semenov-Tian-Shanskij, A. (1920) Revisio synoptica Cleptidarum faunae rossicae (Hymenoptera Proctotrypodea). Bulletin de l'Académie des Sciences de Russie, 14 (1920), 303-328.

Solander, D. (1759) Letter L2599, Letter written by Daniel Solander, Letter addressed to Carl Linnaeus, Date 15 October 1759. Summary. Available from: http://linnaeus.c18.net/Letters/display_sum.php?id_letter=L2599\&person_from=Daniel\%20So lander\& person_to $=$ Carl\%20Linnaeus\&date $=15 \% 20$ October\%201759 (accessed 16 May 2015)

Soon, V. (2010) Chrysis tripotini sp. n., a new cuckoo wasp (Hymenoptera, Chrysididae) from South Korea. Deutsche Entomologische Zeitschrift, 57 (1), 37-41. http://dx.doi.org/10.1002/mmnd.201000003

Straka, J., Bogusch, P., Tyrner, P. \& Vepøek, D. (2004) New important faunistic records of Hymenoptera (Chrysidoidea, Apoidea, Vespoidea) from the Czech Republic. Klapalekiana, 40, 143-153.

Strumia, F. (1995) Hymenoptera Chrysididae. In: Minelli, A., Ruffo, S. \& La Posta, S. (Eds.), Checklist delle specie della fauna italiana. Calderini, Bologna 99, 1-10.

Strumia, F. \& Yildirim, E. (2008 ["2007"]) Contribution to the knowledge of Chrysididae fauna of Turkey (Hymenoptera, Aculeata). Frustula entomologica, N.S., 30, 55-92.

Szczepko, K. \& Wiśniowski B. (2009) Aculeata (Hymenoptera) of the Kampinos National Park Part III. Ruby-tailed wasps (Chrysididae). Wiadomości Entomologiczne, 28 (3), 163-182.

Szczepko, K., Kruk, A., Bartos, M. \& Wiśniowski, B. (2012) Factors influencing the diversity of cuckoo wasps (Hymenoptera: Chrysididae) in the post-agriculture area of the Kampinos National Park, Poland. Insect Conservation and Diversity, 6 (3), 339-353. http://dx.doi.org/10.1111/j.1752-4598.2012.00223.x

Turrisi, G.F. (2009) Faunistic remarks on Sicilian Cleptes Latreille with two new records (Hymenoptera Chrysididae Cleptinae). Il Naturalista siciliano, 33 (3-4), 295-304.

Tyrner, P. (2007) Chrysidoidea: Chrysididae (zlatěnkovití). Acta entomologica Musei nationalis Pragae, 11 (Supplementum), 41-63.

Tyrner, P., Kejval, Z. \& Erhart, J. (2010) Žahadloví blanokřídlí západních Čech - 1. Zlatěnky (Hymenoptera: Chrysididae). Západoèeské entomologické listy, 1, 42-58.

Wei, N-S., Rosa, P. \& Xu, Z-F. (2013) Revision of the Chinese Cleptes (Hymenoptera, Chrysididae) with description of new species. Zookeys, 362, 55-96. http://dx.doi.org/10.3897/zookeys.362.6175

Yildirim, E. \& Strumia, F. (2001 ["2000"]) Contribution to the knowledge of Chrysididae fauna of Turkey. Part 1: Cleptinae (Hymenoptera: Chrysididae). Frustula entomologica, N.S., 33, 161-166.

Zimmermann, S. (1954) Hymenoptera-Tubulifera: Cleptidae, Chrysididae. Teil XVI. Catalogus Faunae Austriae, SpringerVerlag, Wien, 1-10. 